\title{
THE ECONOMIC, SOCIAL, AND SPIRITUAL EFFICIENCY OF THE ECONOMIC SYSTEM: APPROACHES TO ASSESSMENT
}

\author{
Dmitrii Yadranskii ${ }^{1}$, Viktor Chigrin' ${ }^{2}$, Elena Chumak ${ }^{3}$
}

\begin{abstract}
The article considers the categories of social, economic, and spiritual efficiency. The emphasis is made on the crisis of modern economic processes. The subject of the article is the contradictions arising in the process of increasing economic efficiency. Existing methodological approaches to the study of these categories are critically reviewed. The main goal of the article is to create the author's concept of overcoming the contradictions between the growth of economic and social efficiency in the conditions of modern economic organizations. The concept is based on the conflict paradigm. The methodological basis of the study consists of the concepts of foreign and domestic researchers dealing with the effectiveness of social reproduction. The main theoretical concept is neo-Marxism. The purpose of the article is to determine the methodology for reconciling contradictions arising in the process of managing the economic efficiency of an economic system. The thesis of P. Drucker on the inevitability of aggravating the economic crisis is considered as the cause of the conflict. In combination with the totality of such general scientific and special methods of cognition as dialectic, systemic, descriptive, theoretical modelling, the article reveals the main contradictions in the assessment of the growth of the economic and social efficiency of the economic system. The main conclusion of the article is the need to abandon the use of singlefactor methods for evaluating the effectiveness of the functioning of economic systems. The main problem is the fact that the growth of economic efficiency most often has a non-linear effect on the change in social and spiritual efficiency. Therefore, it is necessary to use at the same time changes in all three specified directions of efficiency, so one can determine the general vector of changes in the economic system. As a final conclusion, it was proposed to apply the efficiency rule proposed by Pareto to this assessment, according to which the system state is optimal when the value of each particular criterion describing the system state cannot be changed without deteriorating other system indicators. The article presents a table, in which the contradictory changes that are the result of a number of managerial influences are demonstrated for economic and social efficiency. A logical formula for determining the effectiveness of changes in the efficiency of the economic system, based on the indices of changes in individual quantitative indicators, is proposed. Criteria are defined that make it possible to quantify each of the blocks determining efficiency: economic, social, and spiritual. An assessment of possible indicators at the macroeconomic and microeconomic level is given. The article formulates a model for establishing the balance (optimum) of individual indicators of the total efficiency of the economic system. This model is based on the balance of economic interests of employers (owners) and social interests of workers, coordinated through culture, which is defined as one of the priorities of spirituality. A formula is proposed that enables the analytical establishment of the optimal (balance) state of the efficiency of the economic system. On the basis of the conducted research, it becomes possible to talk about a fair (reasonable) distribution of value added. In fact, at the theoretical level, an economic model for managing the socio-economic efficiency of the economic system is proposed, which creates the prerequisites for the effective management of the socioeconomic development of an organization in a permanent crisis environment.
\end{abstract}

Key words: efficiency, factor, productivity, economic, social, balance of interests, contradictions.

JEL Classification: P47, C52

\footnotetext{
Corresponding author:

${ }^{1}$ Ural State University of Economics, Russian Federation.

E-mail: jadransky@yandex.ru

${ }^{2}$ V.I. Vernadsky Crimean Federal University, Russian Federation.

E-mail: sociochigrin@mail.ru

${ }^{3}$ Ural State University of Economics, Russian Federation.

E-mail: lena22021977@yandex.ru
} 


\section{Introduction}

The process of development of social reproduction at the present stage is constantly confronted with inextricably linked and, at the same time, contradictory processes. On the one hand, there is the need to constantly increase labour productivity and, on the other, the need to stimulate consumption. The relevance of the topic is related to the fact that despite the existing research results, the majority of business systems consider economic efficiency as the main indicator of the effectiveness of an economic entity. Such an approach in modern conditions invariably leads to a violation of either the social efficiency of the system itself (for example, a decrease in the social wellbeing of workers), or a decrease in the social efficiency of systems of another level (the release of workers leads to an increase in unemployment, a decrease in aggregate demand, etc.). This said, the growth of economic efficiency is a task related to the goals of social development, which is why it is the most important task of any economic system. The aforesaid, in our opinion, gives rise to a scientific problem to be grasped. The novelty of the topic is that in the conditions of the current crisis economy, the categories "economic", "social", and "spiritual efficiency" were not considered in unity.

At the beginning of theorizing, we suggest specifying a thesaurus. In particular, efficiency is one of the basic characteristics of the economy and an indicator of its success. Starting with the works of K. Marx, "the degree of wealth is not measured by the absolute value of the product but by the relative value of the surplus product" (Marx, 1973). In other words, efficiency is the ratio of results to costs incurred to achieve them (Gavrilishin, 2000). At the same time, modern economics often uses the term productivity as a final indicator of system efficiency.

In accordance with the definition of the Modern Economic Dictionary, productivity is a quantity that characterizes the amount of a useful product obtained from a certain source (Rajzberg, 2006). However, in relation to economic systems, these concepts, in our opinion, are almost identical. Thus, the Great Soviet Encyclopaedia, speaking of economic efficiency, examines the relationship between the results of production - production and material services, on the one hand, and labour costs and means of production on the other (Bolshaja sovetskaja entsiklopedija, 1969). It should be noted that in most modern economic sources, the subject of obtaining an increase in productivity is not specified. Considering this process on the example of the transformation of Marxism, it can be stated that K. Marx noted: "The value of labourpower is determined by the value of the necessaries of life habitually required by the average labourer. The quantity of these necessaries is known at any given epoch of a given society, and can therefore be treated as a constant magnitude" (Marx, 1973). In other words, an increase in employee income due to an increase in his productivity was not considered. The representative of neo-Marxism, Jürgen Habermas, has already seen this problem somewhat differently. In his opinion: "The role of employee loses its debilitating proletarian features with the continuous rise in the standard of living, however differentiated by stratification" (Habermas, 1985). Considering this phrase in the context of his article, it can be stated that it is about the fact that part of the increase in living standards occurs due to an increase in the part of the value added in the employee's wages. This very situation is often associated with an increase in social efficiency (in relation to an employee). At the same time, with respect to social efficiency in relation to the organization as a whole, the growth of employee income is rarely considered. However, the relevance of P. Drucker's thesis in 2002 did not diminish in 16 years: "It is futile, for instance, to try to ignore the changes and to pretend that tomorrow will be like yesterday, only more so. This, however, is the position that existing institutions tend to adopt in such a period - businesses as well as nonbusinesses" (Drucker, 2000).

\section{The problem statement of research}

The above processes form a special relevance of conducting such a study for the purpose of clarifying the nature of the relationship between social, economic, and spiritual efficiency. Achieving the purpose requires the simultaneous implementation of a number of tasks, in particular: study the transformation of scientific ideas about the category of "efficiency" in the modern economy; analyse the relationship of social and economic effect; formulate a mechanism for determining the equilibrium parameters of economic and social efficiency.

In this regard, we consider it expedient to get ahead of the logical mechanism for reconciling the contradictions between the growth of economic productivity and changes in social and spiritual efficiency in relation to the labour process, taking into account the predicted permanent economic crisis.

\section{Social and economic effect: unity and contradictions}

Developing the idea of the permanence of the economic crisis, a modern worker, acting as a reproductive resource, also acts as an object of the economy. In the course of such activities, the economic effect is directly opposed to the social effect. At the same time, the Russian author L. Isaeva considers the social effect as a function of using the economic effect. According to her, "the increase in the economic effect directly depends on the social effect" (Isaeva, 2012). Thus, we come to the idea of the mutual transition of 
the economic effect into the social one and vice versa. Herewith, in the first approximation, cooperation (readiness for cooperation) can be considered a sign of a social effect, while the conflict is a sign of an economic effect (as a factor in the aggravation of contradictions). Nevertheless, as practice shows, these categories in relation to the labour process are also capable of mutual transformation.

Considering the relations arising in the labour process, B. Genkin identifies two main types of human interaction: competition and cooperation (Genkin, 2003). At the same time, these relations can be modified depending on the situation. In particular, in a normal production process, the relationship between workers is of cooperation nature, and in the process of production changes (increased productivity, reduction) is transformed into the competition. Under the conditions of replacing manual labour with an automated one, on the one hand, the amount of manual labour of workers decreases (cooperation with the administration), which transforms into competition not only among workers, but also between workers and equipment (the cost of human labour versus depreciation costs). In the context of interaction between the employee and the employer (shareholder), in accordance with the theory of conflict of K. Marx, the relationship is based on conflict (value added distribution), but in a crisis, cooperation may arise in the process of preserving jobs (business).

In our opinion, the relationship between economic and social efficiency is objective, however, its character depends on the vector of the proposed changes and on the state of spirituality in a particular society. So, as a result of a unilateral increase in economic efficiency, the social effect of labour activity will worsen in two cases:

- the employee acts as an object of immediate savings (he/she is laid off or his/her wages are reduced, his/ her productivity is increased while the level of income remains the same),

- living labour acts as an alternative to material resources (the use of which may be more economically viable). Herewith, such an activity worsens both the social condition (well-being) of a particular subject of labour relations and the macro-social parameters of social reproduction (total employment, use of labour resources, etc.).

In this context, the idea of B. Salikhovlooks interesting. He notes that the core of the modern socio-economic theory is property theory, and the theory of property transformation, which studies the laws of appropriation, serves as a tool for resolving contradictions between the ethics of a competitive market and the ethics of society (Salikhov, 2006). In this vein, we are talking about the possibility of establishing the relationship between economic and social efficiency, based on the laws of appropriation.

Speaking about efficiency (both social and economic), we should recall the rule of efficiency proposed by
V. Pareto. According to this rule, the optimal state of the system is that the value of each particular criterion describing the state of the system cannot be improved without deteriorating the position of other elements (Blyumin, 1962).

Consequently, based on the logic of optimal equilibria, we can assume the possibility of describing an equilibriumoptimal model of social and economic efficiency based on modern appropriation laws. Since social efficiency is the correspondence of the results of economic activities to the basic social needs of society (Pokropivnii, 2001), it is possible to ascertain the effect of this balance on the efficiency of the entire social system.

Approaching the definition of the logic of equilibrium (balance) of antagonistic indicators characterizing the labour process, it is advisable to dwell on the essence of contradictions, which are displayed in Table 1.

Consequently, any measures aimed at organizational changes in order to increase labour productivity cannot be considered as such unequivocally. We associate the latter with the fact that their social consequences may have a demotivating (or directly opposite) effect. Thus, the growth of productivity, leading to an increase in value added, while worsening the social parameters of the organization does not lead to a general increase in the efficiency of the economic system.

Such a situation can be also considered in a macroeconomic context. Thus, the introduction of new technology in production processes, being a significant factor in increasing productivity, which leads to a reduction in the production cycle. Consequently, the intensity of labour increases, as well as, as a rule, there is an improvement in working conditions. However, on the one hand, there is a release of individual workers, and on the other, responsibility increases (the psychological burden of the operator). In other words: productive employment decreases at the macroeconomic level, and mental stress increases at the level of the worker. All of the above suggests that the overall efficiency of the economic system can be represented by the expression (1)

$$
Э \phi \Leftrightarrow Э \kappa_{\ni \phi}+\operatorname{Cou}_{\ni \phi}+Д y x_{э \phi} \leq 1
$$

At the same time, it should be noted that for practical use of such logic, it is necessary to solve the problem of quantitative measurement of the proposed indicators. As parameters, we propose to use the indicators given in Table 2. It is proposed to determine their quantitative value in the form of coefficients of the ratio of the base period of analysis to the actual one.

In Table 2, we selected indicators that, in our opinion, can have a quantitative expression, and accordingly presented in an index form can characterize the changes taking place. On this basis, we assume that in the case of a general increase in efficiency, the value of $Э \phi$ (1) should exceed 1. Other indicators can also be used as alternative indicators while having an unambiguous quantitative assessment. 
Vol. 4, No. 4, 2018

Table 1

The contradictory achievement of social and economic effect

\begin{tabular}{|c|c|c|c|c|}
\hline \multirow{2}{*}{ Economic act } & \multicolumn{2}{|c|}{ Economic effect } & \multicolumn{2}{|c|}{ Social effect } \\
\hline & positive & negative & positive & negative \\
\hline $\begin{array}{l}\text { Improving } \\
\text { the level } \\
\text { of education } \\
\text { of workers }\end{array}$ & $\begin{array}{l}\text { The possibility of increasing } \\
\text { labour productivity in the } \\
\text { future; } \\
\text { Improving the quality of work; } \\
\text { Reducing the loss of working } \\
\text { time (with the expansion of } \\
\text { areas of responsibility). }\end{array}$ & $\begin{array}{l}\text { Cost increase; } \\
\text { Loss of working time } \\
\text { over the diversion of } \\
\text { workers to education; } \\
\text { Weak predictability of } \\
\text { the result. }\end{array}$ & $\begin{array}{l}\text { Improving the image of the } \\
\text { enterprise; } \\
\text { Increasing employee } \\
\text { loyalty; } \\
\text { Improving the } \\
\text { competitiveness of the } \\
\text { organization. }\end{array}$ & $\begin{array}{l}\text { Increasing the competitiveness } \\
\text { of workers in the labour market; } \\
\text { The growth of social } \\
\text { expectations of the employee; } \\
\text { The possibility of disclosure } \\
\text { of trade secrets as a result of } \\
\text { step out. }\end{array}$ \\
\hline $\begin{array}{l}\text { Reducing physical } \\
\text { stress on workers }\end{array}$ & $\begin{array}{l}\text { Salary reduction; } \\
\text { Staff reduction; } \\
\text { Labour productivity growth. }\end{array}$ & $\begin{array}{l}\text { Costs for production } \\
\text { modernization; } \\
\text { The need to reassign } \\
\text { (dismiss) workers; } \\
\text { Increase in depreciation } \\
\text { costs. }\end{array}$ & $\begin{array}{l}\text { Reducing risks associated } \\
\text { with staff; } \\
\text { The growth of internal } \\
\text { competition of personnel; } \\
\text { Reducing employee fatigue. }\end{array}$ & $\begin{array}{l}\text { The growth of social tension } \\
\text { in the team; } \\
\text { The possibility of disclosure } \\
\text { of trade secrets; } \\
\text { The growth of the } \\
\text { psychological burden on staff. }\end{array}$ \\
\hline $\begin{array}{l}\text { Improving } \\
\text { the environmental } \\
\text { situation }\end{array}$ & $\begin{array}{l}\text { Reduction in the tax burden } \\
\text { (fines); } \\
\text { Reduction in environmental } \\
\text { restoration costs } \\
\text { Reduction in employee benefits } \\
\text { for working conditions; } \\
\text { Possible expansion of } \\
\text { the range due to recycled } \\
\text { products. }\end{array}$ & $\begin{array}{l}\text { The cost of equipment } \\
\text { and training of } \\
\text { personnel; } \\
\text { Increase in production } \\
\text { costs; } \\
\text { The cost of staff } \\
\text { development; } \\
\text { Organization of sales of } \\
\text { by-products. }\end{array}$ & $\begin{array}{l}\text { Reduction in the man-made } \\
\text { burden on workers and } \\
\text { residents; } \\
\text { Improving the image of the } \\
\text { enterprise; } \\
\text { Improving the health of } \\
\text { workers and the public. }\end{array}$ & $\begin{array}{l}\text { Possible change in } \\
\text { requirements for staff; } \\
\text { Possible increase in social } \\
\text { tension due to changes in staff } \\
\text { structure. }\end{array}$ \\
\hline $\begin{array}{l}\text { Improving } \\
\text { working } \\
\text { conditions }\end{array}$ & $\begin{array}{l}\text { Reduction in the cost of } \\
\text { social insurance (disability } \\
\text { payments); } \\
\text { Reduction in the cost of } \\
\text { compensation to staff; } \\
\text { Tax (fines) cuts. }\end{array}$ & $\begin{array}{l}\text { Costs associated with } \\
\text { changes in working } \\
\text { conditions; } \\
\text { Costs of staff } \\
\text { development; } \\
\text { Costs for maintaining } \\
\text { improved working } \\
\text { conditions. }\end{array}$ & $\begin{array}{l}\text { Improving employee health; } \\
\text { Improving the image of the } \\
\text { enterprise; } \\
\text { Reducing physical } \\
\text { requirements for employees. }\end{array}$ & $\begin{array}{l}\text { Decreased loyalty as a result } \\
\text { of reduced social benefits; } \\
\text { Lower wages over the } \\
\text { improved working conditions. }\end{array}$ \\
\hline $\begin{array}{l}\text { Organization } \\
\text { of rest (food) } \\
\text { of workers }\end{array}$ & $\begin{array}{l}\text { Reducing disability benefits } \\
\text { (gastrointestinal problems); } \\
\text { Reduction in the loss of } \\
\text { working time (due to the } \\
\text { precise regulation of time for } \\
\text { rest and personal needs); } \\
\text { Increasing productivity. }\end{array}$ & $\begin{array}{l}\text { Cost increase; } \\
\text { The distraction of } \\
\text { leadership to perform } \\
\text { secondary tasks; } \\
\text { Organization and } \\
\text { maintenance of the } \\
\text { service system. }\end{array}$ & $\begin{array}{l}\text { Improving the image of the } \\
\text { enterprise; } \\
\text { Increase in employee loyalty; } \\
\text { Improving employee health; } \\
\text { Income growth is possible } \\
\text { as a result of increased } \\
\text { productivity. }\end{array}$ & $\begin{array}{l}\text { Increased fatigue due to } \\
\text { greater productivity; } \\
\text { Reducing loyalty due to a } \\
\text { lack of understanding of } \\
\text { advantages; } \\
\text { Decreased loyalty over the } \\
\text { impression of increased control. }\end{array}$ \\
\hline Rise of income & $\begin{array}{l}\text { Increased productivity as } \\
\text { a result of reduced staff } \\
\text { turnover; } \\
\text { Growing purchasing power; } \\
\text { Possible increase in labour } \\
\text { activity (innovations, etc.). }\end{array}$ & $\begin{array}{l}\text { Cost increase; } \\
\text { Change in cost } \\
\text { structure. }\end{array}$ & $\begin{array}{l}\text { Increased employee } \\
\text { interest; } \\
\text { The influx of the most } \\
\text { qualified and productive } \\
\text { workers; } \\
\text { Improving the image of the } \\
\text { organization. }\end{array}$ & $\begin{array}{l}\text { Reduction in the motivational } \\
\text { effect of the additional } \\
\text { amount of money; } \\
\text { Increasing competition; } \\
\text { The deterioration of the social } \\
\text { environment as a result of } \\
\text { possible reductions (caused } \\
\text { by productivity growth); } \\
\text { Restrictionism is possible. }\end{array}$ \\
\hline $\begin{array}{l}\text { Increase in salary } \\
\text { differentiation }\end{array}$ & $\begin{array}{l}\text { The growth of motivation and } \\
\text { productivity; } \\
\text { Improving the efficiency of } \\
\text { the use of payroll budget; } \\
\text { Possible savings on payments } \\
\text { to unproductive workers. }\end{array}$ & $\begin{array}{l}\text { Possible cost increase; } \\
\text { There may be problems } \\
\text { with trade unions } \\
\text { (employees, including } \\
\text { the judicial ones); } \\
\text { Possible increase in staff } \\
\text { turnover. }\end{array}$ & $\begin{array}{l}\text { Increased employee } \\
\text { interest; } \\
\text { The influx of the most pay- } \\
\text { oriented workers; } \\
\text { Reducing the value } \\
\text { component in the internal } \\
\text { relations. }\end{array}$ & $\begin{array}{l}\text { Increased number of conflicts } \\
\text { in the staff; } \\
\text { Increased emotional stress; } \\
\text { Possible deterioration of the } \\
\text { image of the organization. } \\
\text { Changing the social structure } \\
\text { of the staff. }\end{array}$ \\
\hline $\begin{array}{l}\text { Increase in social } \\
\text { satisfaction }\end{array}$ & $\begin{array}{l}\text { Increase productivity by } \\
\text { changing attitudes to work. }\end{array}$ & $\begin{array}{l}\text { Increase in expenses; } \\
\text { Increasing complexity of } \\
\text { the forms and methods } \\
\text { of working with staff. }\end{array}$ & $\begin{array}{l}\text { Image enhancement; } \\
\text { Increased staff loyalty; } \\
\text { Improving the social climate } \\
\text { in the organization. }\end{array}$ & $\begin{array}{l}\text { Lack of desire (mood) for } \\
\text { change; } \\
\text { Increasing social demands } \\
\text { and social expectations. }\end{array}$ \\
\hline
\end{tabular}


Table 2

Indicators for quantitative estimation of the change in productivity

\begin{tabular}{|c|l|l|l|}
\hline $\begin{array}{c}\text { № } \\
3 / \Pi\end{array}$ & \multicolumn{1}{|c|}{ Economic effect } & \multicolumn{1}{c|}{ Social effect } & \multicolumn{1}{c|}{ Spiritual effect } \\
\hline 1 & Return on investment & Working conditions & Labour discipline \\
\hline 2 & Labour intensity & Number of sick lists & Satisfaction with the organization \\
\hline 3 & Labour productivity & $\begin{array}{l}\text { Professional development } \\
\text { of employees (advancement) }\end{array}$ & $\begin{array}{l}\text { The number of undesirable actions of employees } \\
\text { (by type of action) }\end{array}$ \\
\hline 4 & Gross income & Accident frequency rate & $\begin{array}{l}\text { Opportunities for personal growth (number of participants } \\
\text { in non-production activities and competitions) }\end{array}$ \\
\hline 5 & Production (labour) cycle duration & Continuity of personnel & $\begin{array}{l}\text { The number of decisions made based on employees' } \\
\text { recommendations }\end{array}$ \\
\hline
\end{tabular}

According to the results of the theoretical analysis, it can be stated that social and economic effects have not only contradictions among themselves but also internal ambivalence. Because of this, conducting a parametric (quantitative) analysis of these indicators is an important task of economics.

\section{Equilibrium parameters of economic and social efficiency}

Since the quantitative measurement of indicators of economic efficiency in modern literature is sufficiently developed, it is advisable to pay attention to the identification of possible indicators of social efficiency. In this case, indicators that give an idea of the quantitative side of achieved social goals (social results) can serve as criteria. In this case, these indicators should be considered at two levels: micro and macro. At the micro level, such indicators can be the saving of working time (provided that employment and income security are preserved), improvement of working and living conditions, provision of additional social services, housing. At the macro level, social indicators include changes in the consumer price index, improvement of the environment, increased general safety of life, reducing unemployment, an increase in the birth rate, and an increase in the index of social well-being. We attribute the change in the level of income of workers to economic efficiency indicators.

Speaking about economic efficiency, it is necessary to pay attention to the principles of efficiency formulated by Harrington Emerson: precisely set goals; common sense; competent counsel; discipline; fair deal with staff; fast, reliable, complete, accurate, and constant accounting; despatching; standards and schedules; standardized conditions; standardized operations; standard instructions; efficiency reward (Emerson, 1992). Almost all of the above principles are related to the activities of the staff, their competence, common sense, remuneration (that is, the categories disclosed in the framework of assessing social and spiritual effectiveness). We consider possible to use the principles proposed by H. Emerson for reconciling contradictions within the establishment of social and economic efficiency. "Spiritual efficiency, being inextricably linked with the material basis and steadily expanding it, nevertheless, manifests its true essence in the area of the spirit, ..., and not in the material wealth surrounding it, although one does not deny the other, and the first is impossible without the second" (Bokachev, 2000). In our opinion, the culture will occupy a special place in the system of spiritual efficiency. Therefore, it can be assumed that contradictions in the system of social efficiency and economic productivity can be resolved in the process of cultural evolution, provided that they meet the criteria of spiritual efficiency.

Thus, we consider possible to formulate a model to establish a balance (optimum) for individual indicators of aggregate efficiency. The principal model of achieving a balance in the productivity of the production system aimed at maximizing profits and social efficiency criteria is shown in Figure 1.

In our opinion, the main limitation of achieving a balance of economic and social efficiency will be the fact that each specific subject of interaction, seeking to maximize its own interests, is not interested in maintaining the principles of balance. This rule is valid under the condition of ignoring the criteria of spiritual efficiency (first of all, culture).

In this context, attention should be paid to the principle of establishing quantitative indicators of the optimum, which characterizes the optimal (equilibrium) state of the system being analysed. In our opinion, the basis of this balance may be the expression (2).

$$
\frac{\Delta C}{\Delta t} \equiv \frac{\Delta R}{\Delta t}
$$

where $C$ - capitalized social effect; $R$ - resulting indicator of economic activity; $t$ - time during which this result was obtained.

According to the results of the analysis, it is possible to formulate the main task of the analysis - to identify changes associated with the violation of the state of optimal balance (equilibrium) between the parameters of economic and social efficiency. Moreover, such a deviation, in our opinion, is undesirable to any of the parties since this, in any case, will adversely affect the parameters of aggregate efficiency. 


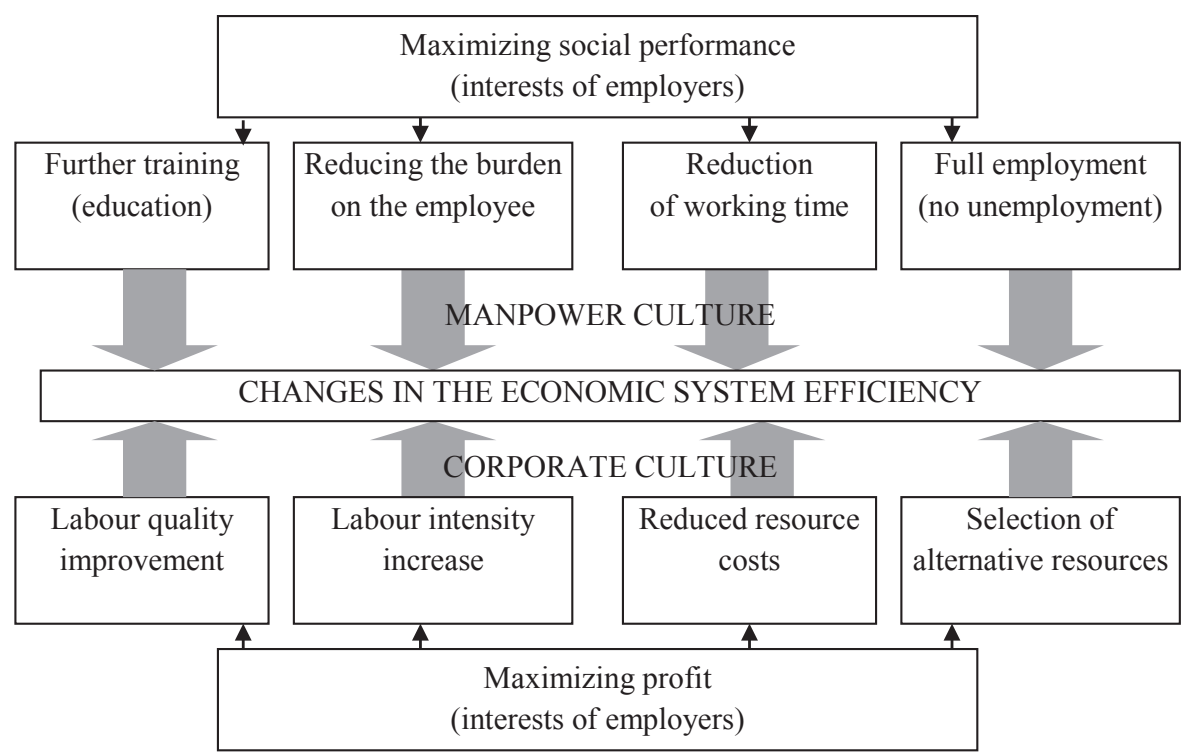

Figure 1. The model of balance (optimality) of interests within the economic system

\section{Conclusions}

Thus, after evaluating the change in efficiency and determining the optimality level of these changes, it becomes possible to talk about a fair (reasonable) distribution of value added. In a down economy, it is possible to change the parameters of social and economic efficiency in a balanced manner without compromising the interests of one of the groups of participants in the reproduction process.

In the framework of this paper, the logic for assessing the total efficiency of the economic system is proposed. The possibility of determining the balance of interests of subjects interested in increasing labour productivity and subjects focused on increasing its social efficiency is also considered. At the same time, any model should be based on the principle of evaluating a modern economic system by the criterion of aggregate efficiency gains. The use of separate criteria for solving these goals, in our opinion, not only does not correspond to the logic of efficiency but can also lead to violations of the principles of optimality of the entire managerial impact. The resolution of these contradictions is based on the principles of the preservation of spirituality (spiritual efficiency). Such an approach, in our view, is an important way of the entire crisis management system, which has yet to be built under a permanent economic crisis.

As specific management indicators, it is possible to use a parametric deviation of an indicator that reveals the economic interests of employers (owners) and social interests of employees. Parameters of culture (personal, corporate) are an integral element in achieving such a balance. Thus, work in the direction of enhancing the spiritual efficiency of activity is also seen by us as an important managerial task.

As the main applied result, we consider the formulation of an empirical basis for obtaining quantitative data on efficiency parameters. The study contains a formula enabling the analytical determination of the optimal (equilibrium) state of the efficiency parameters of the economic system. It is the monitoring of this indicator that we consider necessary to ensure a fair (reasonable) distribution of value added. The main scientific result of this study is the economic model of monitoring the socio-economic efficiency of the economic system. The formulated model creates the prerequisites for improving (maintaining) the effectiveness of managing the socio-economic development of an organization in terms of permanent economic crisis.

\section{References:}

Marx, K. (1973). Kritika polit. ekonomii [Critique of political economy]. Moskow: Izdatelstvo politicheskoj literatury. (in Russian)

Gavrilishin, B. (2000). Ekonomichna entsiklopedija: U 3 t. [Economic Entsiklopediya]. Kyiv. Vidavnichij tsentr "Akademija". (in Ukrainian)

Rajzberg, B. (2006). Sovremennyj ekonomicheskij slovar [Modern economic dictionary]. Moskow: Izdatelstvo politicheskoj literatury. (in Russian)

Bolshaja sovetskaja entsiklopedija (1969) [Great Soviet encyclopedia]. Moskow: Izdatelstvo politicheskoj literatury. (in Russian) 
Habermas, J. (1985). Otnoshenija mezhdu sistemoj i zhiznennym mirom v uslovijah pozdnego kapitalizma [The relationship between the system and the world of life' in the conditions of late capitalism]. Germany.

Drucker, P. (2000). Ferdinand. Zadachi menedzhmenta v XXI veke [Management challenges in the 21st century]. Moskow: Izdatelstvo politicheskoj literatury. (in Russian)

Isaeva, L. (2012). Ekonomicheskaja i sotsialnaja effektivnost $\mathrm{v}$ vosproizvodstvennom protsesse [Economic and social efficiency in the reproductive process]. Voronezh Publishing house of Voronezh state University. (in Russian) Genkin, B. (2003). Organizatsija, normirovanie i oplata truda na promyshlennyh predprijatijah [Organization, regulation and wages in industrial enterprises]. Moskow: Izdatelstvo "NORMA". (in Russian)

Salikhov, B. (2006). Razmyshleniya o predmete ehkonomicheskoj teorii, ili kak povysit ehffektivnost eyo sotsialnoj funktsii [Razmyshleniya o predmete ehkonomicheskoj theory, ili kak povysit ehffektivnost eyo sotsialnoj funktsii]. Izdatelstvo "Finansy i Kredit". (in Russian)

Blyumin, I. (1962). Teoriya Pareto. Material iz Vikipedii - svobodnoj entsiklopedii [Criticism of bourgeois political economy]. Moskow: Izdatelstvo "AN SSSR". (in Russian)

Pokropivnii, S. (2001). Ekonomika pidpriiemstva: [Economics of enterprise]. Kyiv: Vidavnichij tsentr "Akademija". (in Ukrainian)

Emerson, H. (1992). Dvenadtsat printsipov proizvoditelnosti: [Twelve principles of performance]. Moskow: Izdatelstvo "Ekonomika". (in Russian)

Bokachev, I. (2000). Duhovnost v kontekste sotsialno-filosofskogo analiza [Spirituality in the context of sociophilosophical analysis]. Moskow: Izdatelstvo "Delo". (in Russian) 